\title{
Estimasi Jumlah Work Order Project Konstruksi Menggunakan Metode ARIMA (Autoregressive Integrated Moving Average)
}

\author{
Hanik Azharul Hidayah ${ }^{1}$, Richa Fadlilatul Mu'affifah ${ }^{2}$, Umi Chotijah ${ }^{3}$ \\ 1,2,3 Teknik Informatika, Universitas Muhammadiyah Gresik, Gresik \\ e-mail: $\left\{{ }^{1}\right.$ azharulhanik@gmail.com, ${ }^{2}$ Richa19.rf@gmail.com $\},{ }^{3}$ Umi.chotijah@umg.ac.id
}

Submitted Date: August $31^{\text {st }}, 2019$

Revised Date: September $9^{\text {th }}, 2019$
Reviewed Date: September $3^{\text {rd }}, 2019$

Accepted Date: October $4^{\text {th }}, 2019$

\begin{abstract}
A project consists of various types or work. Between one type of work with another type of work has a very close relationship. The types of work will show the scale or failure of a project. The more types of work to be done, the greater the scale of the project, and vice versa. The relationship between the type of work one with the other type of work on a large-scale project will be very complex, the smaller the scale, the relationship between types of work will be simpler. One of the construction companies in Gresik, namely CV. ANEKA JASA TEKNIK, applies the make to order strategy to respond to requests from consumers. That way, the company can send orders with quality and delivery time in accordance with the wishes of consumers. In this project the problem faced is how to forecast project work orders in the coming month. The data used in this study is work order data from January 2016 to April 2019. Data analysis uses the Autoregressive Integrated Moving Average (ARIMA) method. The tools used in this study are Minitab. The analysis obtained from calculations using the ARIMA model $(1,1,1)$ and forecasting results until the month of October. The analysis results obtained from calculations using the ARIMA model $(1,1,1)$ and forecasting results until October. Work order construction project is $\mathrm{Zt}=\mu$ $0,9647 \mathrm{Zt}-1+$ at, Forecasting work order construction projects for the coming month, starting from January 2016 to April 2019 experiencing a gradual decline, comparison between work order forecast project construction not much different from the work order of the actual construction project.Output in the form of data prediction the number of work orders is displayed in the form of tables and graphs so that it is easy to understand.
\end{abstract}

Keywords: ARIMA, Forecasting, Minitab, Work Order, Make to Order

\section{Abstrak}

Suatu proyek terdiri dari berbagai pekerjaan. Jika semakin banyak pekerjaan yang dilakukan maka skala proyek semakin besar dan begitu sebaliknya. Salah satu perusahaan konstruksi yang berada di Gresik, yaitu CV. Aneka Jasa Teknik, menerapkan strategi make to order untuk merespon permintaan dari konsumen. Sehingga perusahaan dapat mengirimkan pesanan dengan kualitas dan waktu pengiriman yang sesuai dengan keinginan konsumen. Pada proyek tersebut masalah yang dihadapi adalah bagaimana meramalkan project work order pada bulan pada bulan yang akan datang. Penelitian ini menggunakan data project bulan Januari 2016 sampai April 2019. Metode Autoregressive Integrated Moving Average (ARIMA) yang digunakan untuk menganalisa data. Tools yang digunakan dalam penelitian ini adalah Minitab. Hasil analisa yang diperoleh dari perhitungan menggunakan model ARIMA $(1,1,1)$ dan didapatkan hasil peramalan hingga bulan Oktober. Work order project konstruksi adalah $Z_{t}=\mu-0,9647 Z_{t}$ $1+$ at. Peramalan work order project kontruksi untuk bulan yang akan datang dimulai pada bulan Januari 2016 sampai bulan April 2019 mengalami penurunan secara perlahan. Perbandingan antara work order project konstruksi hasil ramalan tidak berbeda jauh dengan work order project konstruksi aktual. Output berupa prediksi data jumlah work order yang ditampilkan dalam bentuk tabel dan grafik sehingga mudah untuk dipahami.

Kata kunci: ARIMA, Peramalan, Minitab, Work Order Project, Make to Order 


\section{Pendahuluan}

Suatu proyek terdiri dari berbagai pekerjaan. Jika semakin banyak pekerjaan yang dilakukan maka skala proyek semakin besar dan begitu sebaliknya.

Salah satu perusahaan konstruksi yang berada di Gresik menerapkan strategi make to order untuk merespon permintaan dari konsumen yaitu CV. Aneka Jasa Teknik. Dengan begitu, perusahaan dapat mengirimkan pesanan dengan kualitas dan waktu pengiriman yang sesuai dengan keinginan konsumen. Pada proyek tersebut masalah yang dihadapi adalah bagaimana meramalkan project work order pada bulan yang akan datang. Metode yang digunakan pada masalah yang dihadapi untuk melakukan peramalan adalah metode ARIMA (Autoregressive Integrated Moving Average). Salah satu metode yang menggunakan variabel dependen adalah metode ARIMA yang mengabaikan variabel independen untuk mendapatkan hasil peramalan yang tepat (Salwa, 2018).

Dalam penelitian sebelumnya yang dilakukan (Syarif, 2017) oleh menyimpulkan bahwa metode ARIMA dapat digunakan untuk prediksi pengunjung perpustakaan UIN SUSKA Riau. Model MA dalam ARIMA dilakukan dalam penelitian ini lebih sesuai untuk data pengunjung perpustakaan UIN SUSKA Riau. Hasil dari penelitian ini adalah prediksi pengunjung perpustakaan UIN SUSKA Riau dihari ke 190 TIF 10, TIN 1, SIF 3, MATER 3, TE 2, dan total perhari 24 orang.Berdasarkan penelitian yang dilakukan (Salwa, 2018) menyimpulkan bahwa peramalan bitcoin menggunakan metode ARIMA untuk 30 hari kedepan mengalami penurunan yang di mulai pada tanggal 11 Maret 2018 sampai 9 April 2018. Penelitian yang dilakukan oleh (Elvani, 2016) menyimpulkan pada 24 periode ke depan nilai estimasi peramalan menggunakan metode ARIMA cenderung mengalami peningkatan yang cepat untuk tahun 2016 dan tahun 2017 dengan nilai estimasi peramalan 25.905,506 dan 33.360,761 ton. Dengan hal tersebut perusahaan dapat mengambil dan menentukan keputusan tentang upaya untuk meningkatkan hasil panen kelapa sawit.

Tujuan dari penelitian ini adalah meramalkan work order project konstruksi untuk beberapa bulan ke depan dengan menggunakan metode ARIMA yang dikenal memiliki akurasi yang baik untuk peramalan jangka pendek. Di mana dengan adanya peramalan ini dapat mempermudah perusahaan untuk mengetahui estimasi pekerjaan kedepannya.

\section{Landasan Teori}

\subsection{Jenis-Jenis Pekerjaan}

Jenis pekerjaan pada proyek konstruksi saling berkaitan diantaranya pekerjaan ringan dan pekerjaa berat. Lama atau tidaknya pekerja untuk menyelesaikan satu pekerjaan tergantung dari skill pekerja, kedisiplinan pekerja dan juga dari lingkungan/ keadaan setempat.

\subsection{Sistem Informasi}

Sistem informasi merupakan perpaduan dari user, komputer, dan teknologi informasi yang bekerja untuk mengubah data menjadi suatu informasi. Salah satu yang banyak diterapkan yaitu bidang bisnis. Dalam bidang bisnis ini memiliki tujuan agar dapat memberikan keuntungan yang besar dengan menggunakan kemampuan sistem informasi. Contoh kemampuan dukungan sistem informasi dalam bidang bisnis adalah mempercepat suatu pekerjaan, pengurangan biaya, memudahkan dalam menyimpulkan, dan pelayanan terhadap customer semakin meningkat.

\subsection{Sistem Informasi Manajemen}

Sistem infomasi manajemen merupakan perkembangan dari sistem informasi basis komputer yang digunakan oleh semua tingkat manajemen dan memiliki kebutuhan yang sama dalam suatu organisasi. Pengguna membentuk entitas organisasi dalam perusahaan tentang apa saja yang terjadi dan tertulis pada laporan dan output simulasi yang telah diperhitungkan. Manajer atau non-manajer menggunakan output informasi pada saat membuat keputusan dalam memecahkan suatu masalah, sehingga manajer dapat mengambil keputusan lebih tepat karena dibantu oleh sistem informasi manajemen, dan pengambilan keputusan tersebut dapat menentukan kemajuan dari bisnis yang dijalankan.

\subsection{Konsep Dasar Forecasting}

Forecasting adalah peramalan dari beberapa kejadian yang kemungkinan terjadi pada masa yang akan datang. Forecasting merupakan suatu cara yang tepat untuk mengambil keputusan dari berbagai masalah di banyak bidang, salah satunya yaitu dalam bidang bisnis. Forecasting merupakan dasar perencanaan jangka panjang pada proses industry termasuk bagian administrasi tersebut dapat merencanakan seberapa banyak biaya yang dikeluarkan untuk kedepannya. Sedangkan bagian 
pemasaran dapat membuat perkiraan produk baru atau penarikan terhadap produk lama yang sudah mulai menurun permintaannya di pasaran.

Forecasting berdasarkan waktu dibagi menjadi tiga jenis yaitu, jangka pendek, jangka menengah, dan jangka panjang. Forecasting jangka pendek meramalkan yang membutuhkan periode waktu kurang dari 3 bulan. Forecasting jangka menengah, membutuhkan periode 3 sampai 18 bulan, sedangkan forecasting jangka panjang membutuhkan periode lebih dari satu tahun atau lebih dari 18 bulan. Dan forecasting metode time series banyak digunakan untuk memprediksikan masa yang akan datang berdasarkan kecenderungan datanya.

\subsection{Autoregressive Integrated Moving Average Forecasting (ARIMA)}

Metode ARIMA merupakan gabungan dari model Moving Average (MA) dan Autoregressive $(A R)$ yang terbentuk menjadi model linier dan stasioner yang dikenalkan oleh G.E.P Box dan G.M. Jenkins, dan unruk model non-stasioner yaitu model ARIMA. Klasifikasi model ARIMA terbagi ke dalam empat yaitu Autoregressive (AR), Moving Average (MA), dan Autoregressive Integrated Moving Average (ARIMA) serta Seasonal Autoregressive Integrated Moving Average (SARIMA) yang merupakan turunan dari ARIMA untuk mendapatkan prediksi data yang seasonal.

\section{Autoregressive (AR)}

Model Autoregressive terbentuk dengan ordo $\mathrm{p}(\mathrm{AR}(\mathrm{P}))$ atau $(\mathrm{p}, 0,0)$ dinyatakan sebagai berikut:

$$
\begin{gathered}
X_{t}=\mu^{\prime}+\emptyset_{1} X_{t-1}+\emptyset_{2} X_{t-2}+\cdots \\
+\emptyset_{p} X_{t-p}+\mathrm{e}_{t}
\end{gathered}
$$

Di mana

$$
\begin{array}{ll}
\mu^{\prime} & =\text { konstanta } \\
\emptyset_{p} & =\text { parameter autoregresif ke-p } \\
\mathrm{e}_{t} & =\text { nilai kesalahan pada } \mathrm{t}
\end{array}
$$

2. Moving Average (MA)

Model ordo q (MA(q)) atau $(0,0, q)$ dinyatakan dalam bentuk sebagai berikut:

$$
X_{t}=\mu^{\prime}+\mathrm{e}_{t}-\emptyset_{1} e_{t-2}-\cdots-\emptyset_{q} e_{t-k}
$$

Di mana

$\mu^{\prime} \quad=$ konstanta

$\emptyset_{1}$ sampai $\emptyset_{q}$ adalah parameter moving average. $e_{t-k}=$ nilai kesalahan pada $\mathrm{t}-\mathrm{k}$

3. Metode campuran

a. Proses ARMA

Untuk metode campuran proses AR

(1) dan MA (1), misal ARIMA $(1,0,1)$ dinyatakan sebagai berikut:

$$
\begin{aligned}
& X_{t}=\mu^{\prime}+\emptyset_{1} X_{t-1}+\mathrm{e}_{t}-\emptyset_{1} e_{t-1} \\
& \text { Atau } \\
& \left(1-\emptyset_{1} B\right) X_{t}=\mu^{\prime}+\left(1-\emptyset_{1}\right) e_{t} \\
& \mathrm{AR}(1), \mathrm{MA}(2)
\end{aligned}
$$

b. Proses ARIMA

Pada metode campuran proses ARMA ditambahkan nonstasioneritas, maka model umum ARIMA (p, d, q) dapat terpenuhi. Persamaan ARIMA $(1,1,1)$ adalah sebagai berikut:

$$
(1-B)\left(1-\emptyset_{1}\right) X_{t}=\mu^{\prime}+\left(\left(1-\emptyset_{1} B\right) e_{1}\right.
$$

\section{Pembedaan}

Pertama: AR(1), MA(2)

\section{Autocorelation Function (ACF)}

ACF merupakan korelasi antara data di dalam periode waktu yang dipisahkan dalam lag. Nilai maksimum dan minimum data dapat tetap digunakan untuk plotting meskipun median dari data deret berskala tidak stasioner. Kunci statistik di dalam analisis data deret berskala adalah koefisien autokorelasi yang dapat dilihat dalam rumus berikut:

$$
r_{k}=\frac{\sum_{t=b}^{n-k}(\mathrm{Xt}-\overline{\mathrm{X}})(\mathrm{Xt}+\mathrm{k}-\overline{\mathrm{X}})}{\sum_{t=b}^{n}(\mathrm{Xt}-\overline{\mathrm{X}}) 2}
$$

5. Partial Autocorelation Function (PACF)

PACF digunakan untuk menghitung korelasi secara parsial antara Xt dan Xt-k jika pengaruh dari lag time dianggap terpisah yang bertujuan untuk menetapkan model ARIMA. Nilai sample PACF berorde $\mathrm{k}$ dapat dilihat pada rumus: 


$$
r k k=\left\{\begin{array}{l}
r_{1} \quad \text { if } k=1 \\
\frac{\mathrm{rk}-\sum_{j-1}^{k-1} \mathrm{rk}-1, \mathrm{j} \mathrm{rk}-\mathrm{j}}{k-1} \text { if } k=2,3 \\
1-\sum_{j-1}^{k-1} \mathrm{rk}-1, \mathrm{jr}-\mathrm{j}
\end{array}\right.
$$

\subsection{Minitab}

Minitab merupakan program aplikasi statistika dengan tingkat akurasi tinggi yang digunakan untuk memudahkan user dalam mengolah data statistik. Minitab memiliki keunggulan dalam pengolahan data statistika sosial dan teknik. Beberapa pengolahan data yang ada pada minitab salah satunya yaitu membuat peramalan dengan analisis time series.

\section{Metode Penelitian}

\subsection{Analisa Data}

Langkah - langkah analisa data dalam menggunakan model ARIMA adalah sebagai berikut:

1. Menampilkan plot data untuk mengetahui apakah data berpola atau tidak

2. Melakukan identifikasi model stasioner atau tidak stasioner.

3. Estimasi parameter dengan melakukan uji hipotesis untuk mengetahui signifikan atau tidaknya parameter.

Hipotesis:

$\mathrm{H} 0=$ parameter yang tidak signifikan

$\mathrm{H} 1$ = parameter yang signifikan

Level toleransi $(\alpha)$ :

$5 \%=0,05$

Kriteria uji:

Tolak H0 jika p-value $<\alpha$

4. Verifikasi model

Overfitting dan uji residual adalah cara yang dilakukan untuk menentukam verifikasi model. Apabila memerlukan model yang lebih luas, maka menggunakan overfitting. Uji residual digunakan untuk melihat apakah model data layak atau tidak. Jika hasil verifikasi tidak sesuai, maka model harus di ubah sampai didapatkan model yang sesuai.

5. Peramalan

Peramalan dilakukan setelah sudah ada model yang terpilih. Di bawah ini adalah diagram alir tahapan-tahapan penelitian:

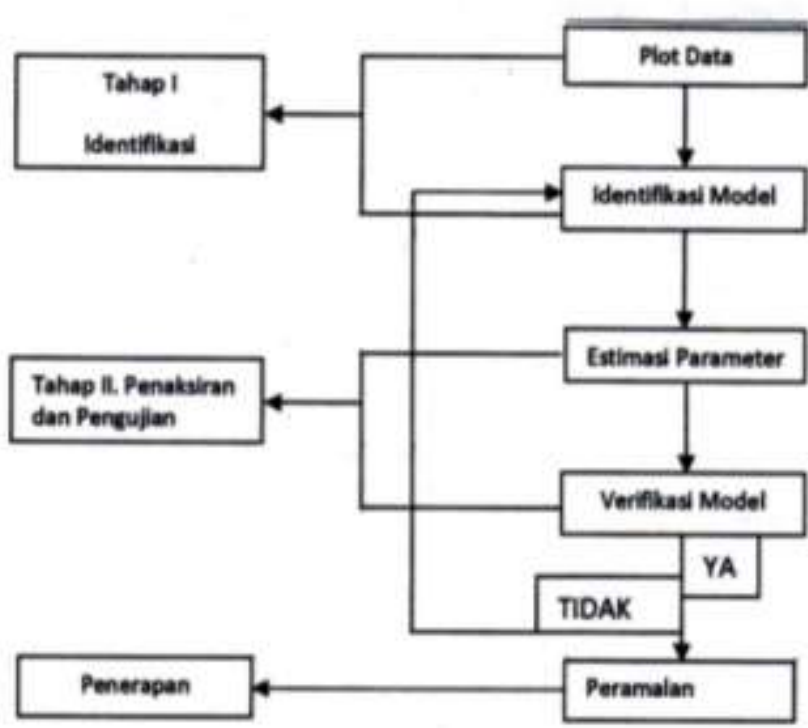

Gambar 1. Diagram alir tahapan penelitian

\subsection{Model ARIMA}

Langkah-langkah dalam metode arima dapat dilihat pada diagram berikut:

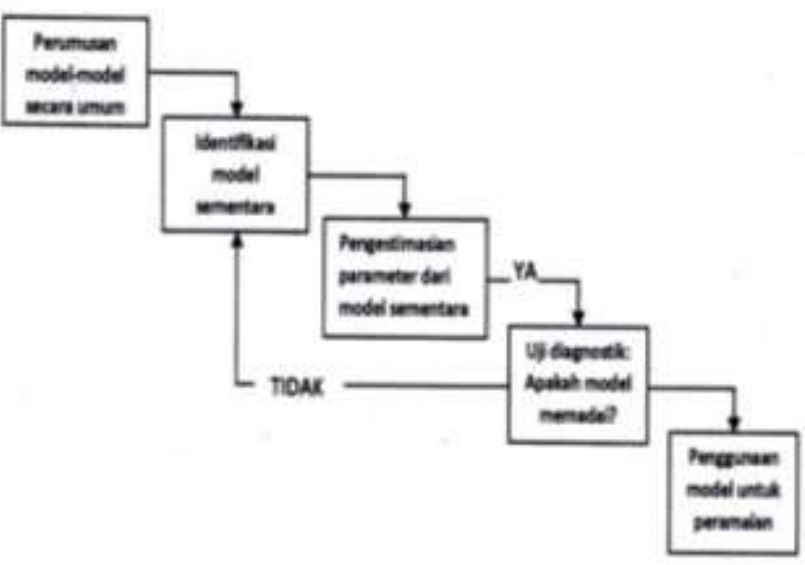

Gambar 2. Flowchart Metode ARIMA

\subsection{Pengumpulan Data}

Sumber primer adalah sumber data yang dihimpun langsung oleh peneliti, sedangkan apabila melalui tangan kedua disebut sumber sekunder. (Turban Dkk, 2005 dikutip oleh Mustakim, 2016).

Data yang digunakan dalam penelitian ini adalah data sekunder. Penulis memperoleh data dengan menerima data rekapitulasi work order project konstruksi bulan Januari 2016 sampai pada bulan April 2019. 
Tabel 1. Data Work Order Project Konstruksi CV.ANEKA JASA TEKNIK

\begin{tabular}{|c|c|c|}
\hline TAHUN & BULAN & PROJECT (Y) \\
\hline \multirow[t]{12}{*}{ Data 2016} & JAN & 5 \\
\hline & FEB & 4 \\
\hline & MAR & 7 \\
\hline & APR & 10 \\
\hline & $\mathrm{MEI}$ & 9 \\
\hline & JUN & 10 \\
\hline & JUL & 13 \\
\hline & AGST & 14 \\
\hline & SEPT & 11 \\
\hline & OKT & 9 \\
\hline & NOV & 12 \\
\hline & DES & 8 \\
\hline \multirow[t]{12}{*}{ Data 2017} & Ke-I & 8 \\
\hline & Ke-II & 5 \\
\hline & Ke-III & 7 \\
\hline & Ke-IV & 10 \\
\hline & Ke-V & 9 \\
\hline & Ke-VI & 14 \\
\hline & Ke-VII & 18 \\
\hline & Ke-VIII & 15 \\
\hline & Ke-IX & 12 \\
\hline & Ke-X & 11 \\
\hline & Ke-XI & 11 \\
\hline & Ke-XII & 13 \\
\hline \multirow[t]{12}{*}{ Data 2018} & Ke 1 & 6 \\
\hline & Ke 2 & 5 \\
\hline & Ke 3 & 3 \\
\hline & Ke 4 & 10 \\
\hline & Ke 5 & 8 \\
\hline & Ke 6 & 6 \\
\hline & Ke 7 & 12 \\
\hline & Ke 8 & 11 \\
\hline & Ke 9 & 14 \\
\hline & Ke 10 & 18 \\
\hline & Ke 11 & 17 \\
\hline & Ke 12 & 11 \\
\hline \multirow[t]{4}{*}{ Data 2019} & Januari & 13 \\
\hline & Februari & 10 \\
\hline & Maret & 9 \\
\hline & April & 11 \\
\hline
\end{tabular}

\section{Hasil dan Pembahasan}

\subsection{Plot Data}

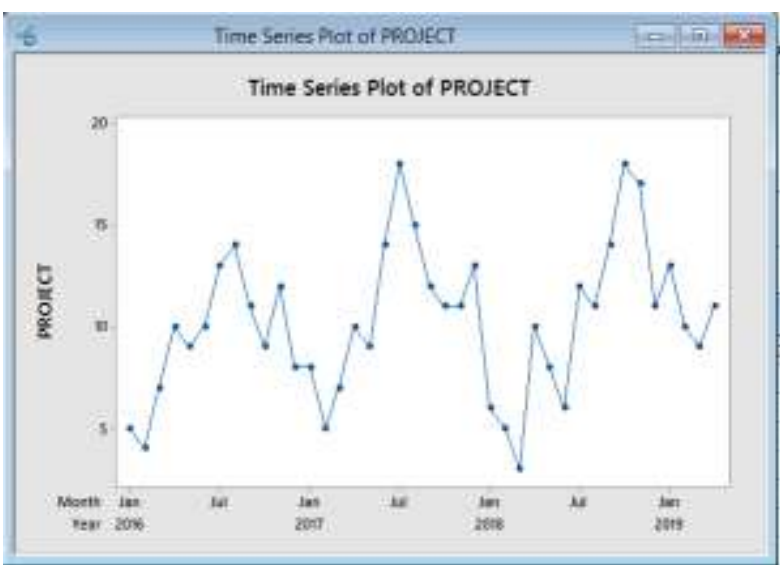

\section{Gambar 3. Plot data work order project konstruksi}

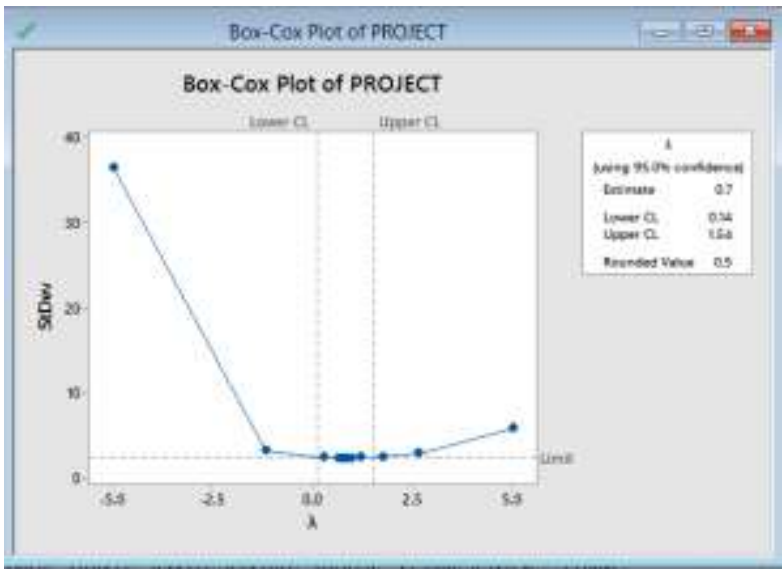

Gambar 4. Box-Cox Plot data work order project konstruksi

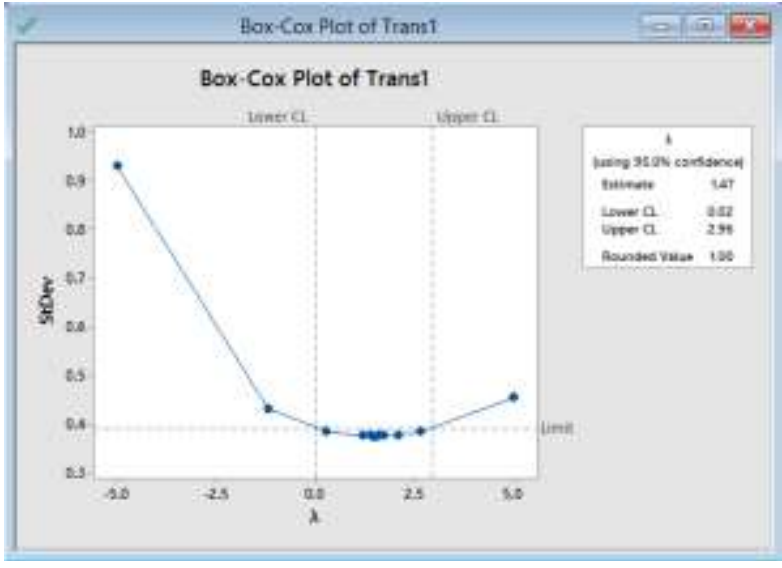

Gambar 5. Box-Cox Plot Trans 1 data work order project konstruksi

Berdasarkan Gambar 3, 4 dan 5 menunjukkan bahwa data work order project konstruksi memiliki pola trend atau mengalami perubahan sepanjang sumbu waktu (tidak 
berfluktasi pada nilai tengahnya). Oleh sebab itu, data work order project konstruksi bulanan dapat dikatakan tidak stasioner.

\subsection{Identifikasi Model}

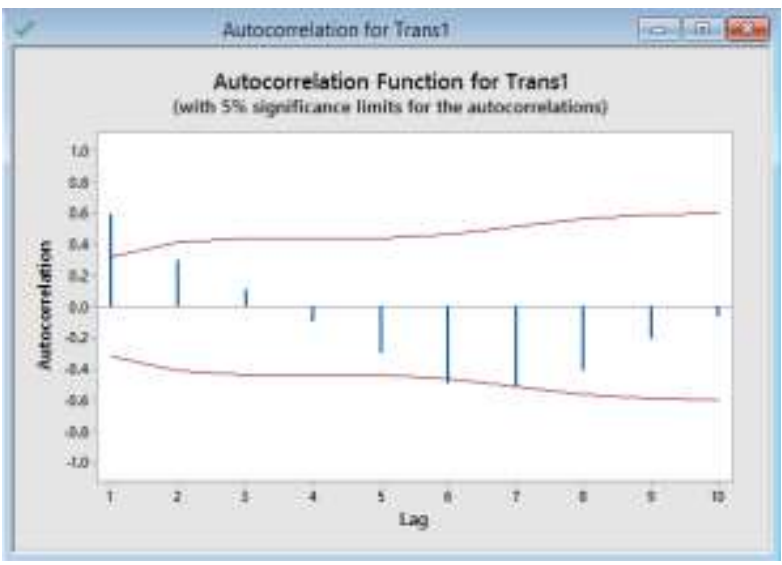

\section{Gambar 6.Plot ACF data work order project konstruksi}

Berdasarkan Gambar 6 memperlihatkan plot $A C F$ yang menunjukkan ketidaksioneran data karena nilai koefisien autokorelasi pada time-lag 1 cukup signifikan dari 0 dan menurun secara perlahan. Selain itu juga koefisien autokorelasi dan autokorelasi parsial berada diluar garis merah (Bartlett).Hal tersebut menunjukkan bahwa data work order project konstruksi tidak bersifat stasioner. Untuk mengatasi masalah ketidakstasioneran data, maka dilakukan proses pembedaan (differencing). Sehingga diperoleh hasil seperti berikut ini:

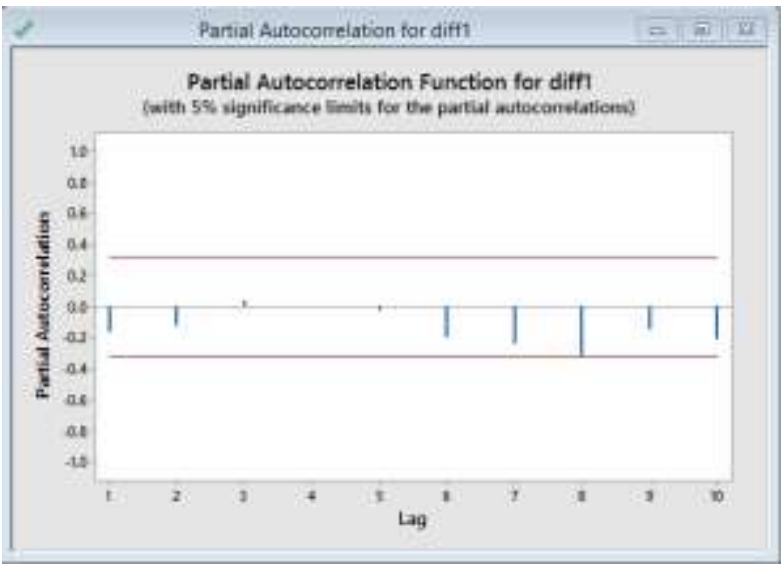

Gambar 7. Plot PACF data work order project konstruksi differencing tingkat 1.

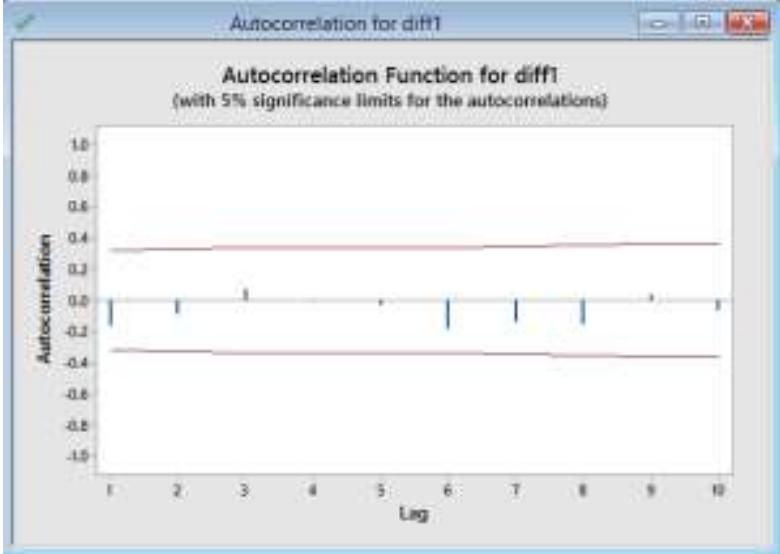

\section{Gambar 8. Plot ACF data work order project konstruksi differencing tingkat 1.}

Berdasarkan Gambar 7 dan 8 menunjukkan bahwa nilai koefisien autokorelasi menurun secara cepat setelah time-lag 1 dan koefisien autokorelasi parsial menurun secara eksponensial maka model sementara didapatkan adalah ARIMA $(1,1,1)$.

\subsection{Estimasi Parameter}

Model sementara yang diperoleh diuji parameternya hingga diperoleh hasil sebagai berikut:

\section{Estimasi parameter dengan trial}

\section{Final Estimates of Parameters}

\begin{tabular}{lrrrrr}
\multicolumn{1}{l}{ Type } & Coef & SE Coef & T-Value & P-Value \\
\hline AR 1 & 0.631 & 0.167 & 3.77 & 0.001 \\
MA 1 & 0.9592 & 0.0875 & 10.96 & 0.000
\end{tabular}

Berdasarkan estimasi parameter dengan trial menunjukkan bahwa $p$-value yang signifikan menggunakan ARIMA $(1,1,1)$. P-value yang didapatkan adalah 0,000 lebih kecil dari $\alpha(0,05)$. Maka keputusan yang diambil adalah tolak H0. Artinya estimasi parameter ARIMA $(1,1,1)$ signifikan. Sehingga diperoleh persamaan untuk ARIMA $(1,1,1)$ sebagai berikut:

$$
Z_{t}=\mu-0,9647 Z_{t-1}+a t 6 r t
$$

\subsection{Verifikasi Model}

\subsubsection{Pengujian Keindependenan Residual}

Kecocokan model diuji dengan mengamati keindependenan distribusi koefisien $A C F$ dan $P A C F$ residualnya. 


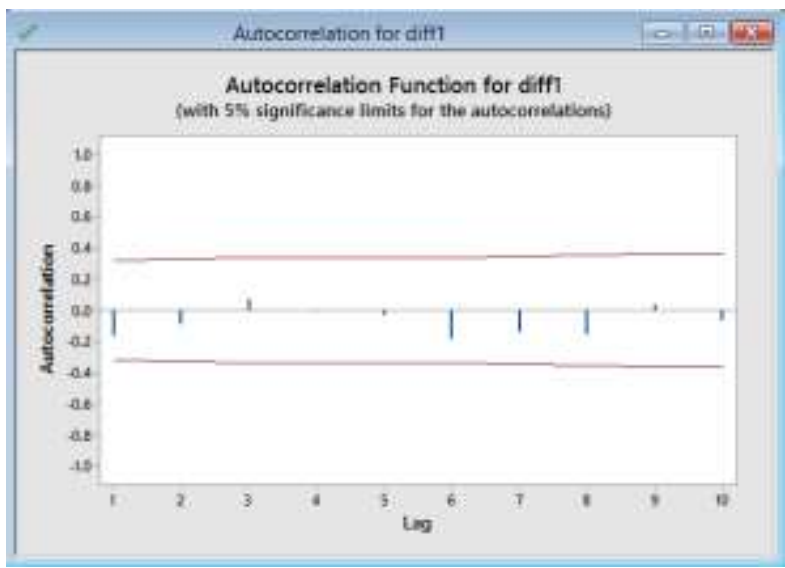

Gambar 9. Plot ACF residual data work order project konstruksi

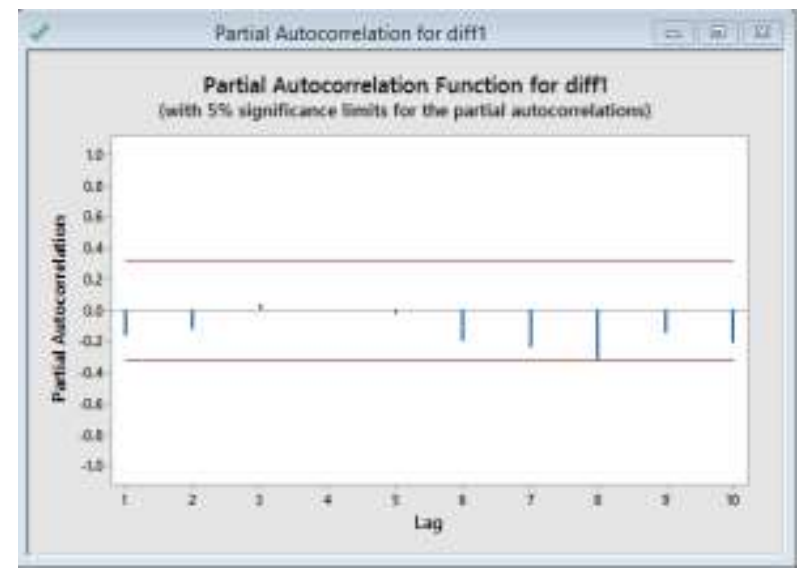

\section{Gambar 10. Plot PACF residual data work order project konstruksi}

Berdasarkan gambar 9 dan 10 menyatakan bahwa pada plot $A C F$ dan $P A C F$ tidak terdapat lag time yang melebihi batas garis merah (Bartlett), yang berarti residual dari model ARIMA $(1,1,1)$ independen atau saling bebas.

\subsection{Peramalan}

Peramalan dilakukan untuk mengetahui berapa banyak project konstruksi untuk bulan yang akan datang diperoleh sebagai berikut:

\section{Hasil ramalan work order project konstruksi}

Forecasts from period 40

\begin{tabular}{rrrrr} 
& & \multicolumn{2}{c}{$95 \%$ Limits } & \\
Period & Forecast & Lower & Upper & Actual \\
\hline 41 & 10.7309 & 4.92433 & 16.5374 & \\
42 & 10.5609 & 3.56418 & 17.5576 & \\
43 & 10.4536 & 2.95326 & 17.9539 & \\
44 & 10.3858 & 2.63787 & 18.1337 & \\
45 & 10.3430 & 2.45798 & 18.2280 & \\
46 & 10.3159 & 2.34590 & 18.2860 & \\
47 & 10.2989 & 2.27000 & 18.3278 & \\
48 & 10.2881 & 2.21440 & 18.3618 & \\
49 & 10.2813 & 2.17064 & 18.3919 & \\
50 & 10.2770 & 2.13399 & 18.4200
\end{tabular}

Berdasarkan ramalan work order proyek konstruksi, menunjukkan hasil peramalan work order project konstruksi tertinggi adalah pada bulan Januari yaitu 10.7309 project dan terendah pada bulan Oktober yaitu 10.2770 project.

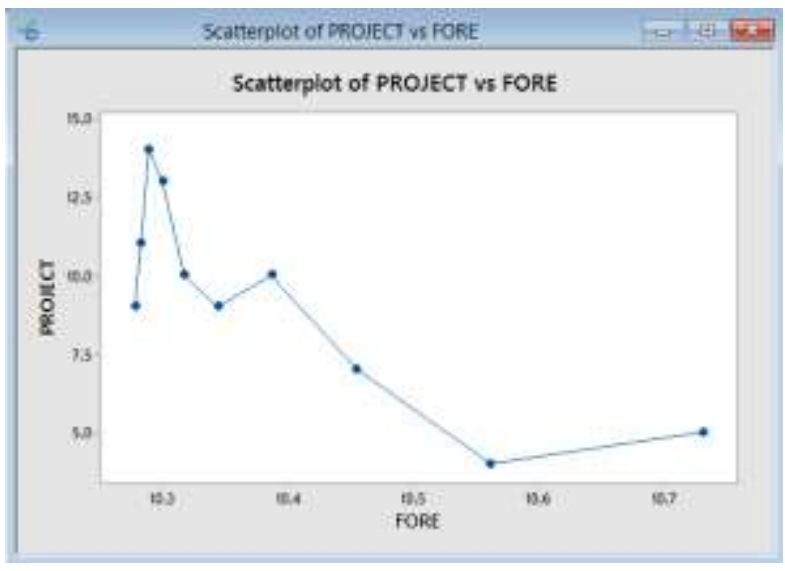

\section{Gambar 11. Grafik perbandingan data work order project konstruksi}

Pada Gambar 11 dapat dilihat bahwa jumlah work order project konstruksi untuk bulan yang akan datang mengalami penurunan secara perlahan dan perbandingan antara work order project konstruksi hasil ramalan tidak berbeda jauh dengan work order project konstruksi actual.

\section{Kesimpulan}

Dari penelitian yang telah dilakukan didapatkan kesimpulan bahwa metode ARIMA dapat digunakan untuk prediksi work order project konstruksi CV. ANEKA JASA TEKNIK Gresik. Model MA dalam ARIMA yang dilakukan dalam penelitian ini lebih sesuai untuk data work order project konstruksi CV. ANEKA JASA TEKNIK. Model ARIMA $(1,1,1)$ dan mendapatkan hasil peramalan hingga bulan Oktober, work order project kostruksi adalah $\mathrm{Z}_{\mathrm{t}}=\mu-0,9647 \mathrm{Z}_{\mathrm{t}-1}+\mathrm{at}$, Peramalan work order project konstruksi untuk bulan yang akan datang yaitu dimulai pada bulan Januari 2016 hingga bulan April 2019 mengalami peurunan secara perlahan, perbandingan antara work order project konstruksi hasil ramalan tidak berbeda jauh dengan work order project konstruksi aktual.

\section{Referensi}

Anwar, S. (2017). Peramalan Suhu Udara Jangka Pendek di Kota Banda Aceh Dengan Metode Autoregressive Integrated Moving Average (ARIMA). Journal of Mechanical Science and Technology, 6-12. 
Desvina, A. P. (2014). Penerapan Metode Box Jenkins Untuk Memprediksi Jumlah Mahasiswa Universitas Islam Negeri SUSKA Riau. Jurnal Sains, Teknologi dan Industri, 1-9.

Elvani, S. U. (2016). Peramalan Jumlah Produksi Tanaman Kelapa Sawit Dengan Menggunakan Metode ARIMA (Autoregressive Integrates Moving Average). ISSN, 1-18.

Meliala, M. S. (2014). Sistem Aplikasi Forecasting Penjualan Elektronik Pada Toko Elektronik Nasional Kabanjahe Dengan Metode Autoregressive Integrated Moving Average. Pelita Informatika Budidarma, 168-172.

Mochammad, A. (2017). Perencanaan Penjadwalan Proyek Pembangunan Rumah Susun Gorontalo. Jurnal Tugas Akhir, 1-10.

Mutiara A, A. M. (2017). Aplikasi Metode Peramalan ARIMA Untuk Meramalkan Permintaan
Produk Benang Di Sinning 4 PT.Apac Inti Corpora,Semarang In Industrial And System Engineering. ISBN, 1-8.

Razak, A. F. (2014). Load Forecasting Using Time Series Models. Jurnal Kejuruteraan, 53-62.

Salwa, N. T. (2018). Peramlaan Harga Bitcoin Menggunakan Metode ARIMA (Autoregressive Integrated Moving Average). Journal Of Data Analysis, 1-11.

Syarif, A. S. (2017, Mei). Penerapan Metode ARIMA Untuk Peramalan Pengunjung Perpustakaan UIN Suska Riau. ISSN, 1-8.

Widjoko, L. (2016). Optimasi Waktu Pelaksanaan Pekerjaan Konstruksi Dengan Metode Jalur Kritis Menggunakan Software Microsoft Project. ISSN, 913-929. 